\title{
Liturgie soos in die GKSA beoefen krities bekyk
}

\author{
B. Spoelstra \\ Dept. Diakoniologie \& Missiologie \\ Potchefstroomse Universiteit vir $\mathrm{CHO}$ \\ POTCHEFSTROOM
}

\begin{abstract}
A critical view of the liturgical procedure in the GKSA

This article attempts a firther analysis of the currem linurgical procedure and posithon of the sor-called worship service in the Refornied Churches of South Africa (GKSA). In thes article the acts or decisions of at least three Sinods of the (BKSA desulmg with the so-called 'elemems' of a worship service (erediens) are analysed. It is argued that the linurgical procedure inherited from the Netherlands ofien falls to constimute a real encoumter in worship he'ween (jod and his congregation. A one-sided imellechal and ins/ructional emphasis on the sermon is of be blamed for this failure.
\end{abstract}

\section{Inleiding}

Allerweë word vandag besef dat kerkwees primêr in die liturgie sigbaar word, tog het liturgie nie in die gereformeerde teologie dieselfde aandag geniet as byvoorbeeld die dogına of kerkregering nie. Die liturgie van die vтoeë kerke was egter hulle "advertensiebord" (Bamard, 1981:174, 191) waarmee hulle proseliete getrek het. Die liturgie van die Rooms-Katolieke en Oosterse Ortodokse Kerke het deur die eeue baie min verander en hulle kerkwees setel grotendeels in liturgie. Die laarboek voor liturgie-onderzoek en Tijdschrift voor Liturgiewetenschap gaan grootliks van Rooms-Katolieke teoloë uit. Mense identifiseer kerk dikwels met liturgie en charisınatiese groepe werf vandag dikwels lede met hulle liturgicse aktiwiteit Daarteenoor gaan talle reformatoriese kerkgemeenskappe betreklik onverskillig en willekeurig met liturgie om. Dikwels word 'n mislukte liturgie geblameer vir onkerklikleeid, "randkerklikheid" en Christelike "geloofslooslieid" (Brienen, 1978:9-14). Moontlik staan gereforneerdes betreklik onverskillig teenoor die liturgie, terwyl van die erediens nog ems gemaak word: gevolglik moet ons vra of die liturgie van ons sogenaamde eredienste slaag.

In 'n artikel "Liturgiese handelinge stel nie vanself 'n erediens as ontmocting met God (godsdiens) daar nie" (Spoelstra, 1994:37 e.v.) is aangedui dat verkeerdelik 
aanvaar word dat 'n erediens'-handelinge (orde) vanself 'n erediens daarstel. Eers wanneer liturgie 'n ontmoeting met God bewerkstellig, kan egter van erediens gepraat word.

Die Kerkorde van die GKSA en Sinodes voor 1924 handel nie oor liturgiese orde nie; tog is liturgie in Nederland vanaf die 16de eeu en in die GKSA vanaf 11 Februarie 1859 in Rustenburg onder die seringbome beoefen. In 1907 dien die eerste versoek dat 'n sinode van die GKSA 'n uitspraak oor 'liturgiese orde' moet doen. Die Sinode ag dit egter onnodig. In hierdie jaar (1907) het in die RoomsKatolieke Kerk ' $n$ beweging begin om die gemeente meer by die liturgie te betrek (Lamberts, 1992:235 e.v.). Dit is egter twyfelagtig of die versoek by die GKSA hiermee verband hou. Die 'toeval' is nietemin interessant. Die GKSA het veral met die ontploffing van gereformeerde teologie aan die Vrije Universiteit byna kinderlik opgesien na die Gereformeerde Kerke van Nederland (GKN). In die GKN het die sogenaande 'jongeren' (moontlik a.g.v. Kuyper se (Onze eeredienst in 1911) ' $n$ beweging begin wat die Sinode te Utrecht (1923) om liturgiese besinning en vernuwing gevra het. Die voorstelle het ook nie sukses behaal nie. In 1924 het H.H. Kuyper, seun van die beroemde Abraham Kuyper en een van die 'jongeren', Suid-Afrika en die Sinode van die GKSA in Rustenburg besoek. Dit is moontlik dat die vraag oor die liturgiese orde daarom juis te Middelburg Kaap op die Sinode van 1924 ter tafel gekom het en die GKSA deputate opgedra is om aan die Sinode van 1927 daaroor te rapporteer. Besluite oor die sogenaande liturgiese orde kom in 1927, 1955 en 1985 in die Handelinge van die GKSA voor. Ten spyte van die jongste besluite (GKSA, 1985:398-425) is eksperimente met liturgie tans op talle plekke aan die gang en die GKSA loop gevaar om soos die CRC in die VSA by chaos uit te kom (vir chaos in die CRC vgl. Brink, 1991:1214). Liturgie is die mees basiese kerkorde (Spoelstra, 1994) en liturgiese willekeur versteur kerklike eenheid.

Omdat kerkwees wesenlik saamhang met die liturgie waarin God ontmoet (moet?) word, moet die reëlings en bepalings oor liturgiebeoefening deur die GKSA krities bekyk en gëevalueer word ten opsigte van wat beoog en bereik is. Hier moet veral oorweeg word of die motief in die 'liturgiese orde' werklik op 'n ontmoeting tussen God en sy gemeente gerig is en of dit nie moontlik op 'n plegtige geleentheid vir godsdiensonderrig in plaas van godsdiensbenefening gerig is nie. In hierdie verband moet in ag geneem word dat die humanisme ook die kerklike visie op die liturgie beinvloed het sodat aangeneem kan word dat waar die liturgie kenuis meedeel en versprei, die mens verander en in verbinding met God gestel word. So sou die preek tot die dominerende element in die liturgie verhef word. Die liturgie van die GKSA soos ooreengekom m sinodale handelinge (rapporte en besluite) bied dus ' $n$ wye en afgebakende veld vir ondersoek en evaluering. 


\section{Die amptelike handelinge van die GKSA met betrekking tot liturgie}

\subsection{Periode van eenheid sonder voorskrifte}

Dit staan vas dat die gangbare liturgie in Nederland sedert 1652 ook in SuidAfrika gevolg is sonder om vrae te vra. Anders as in Nederland het pioniersomstandighede in die verskuiwende en afgesonderde voorposte met baie ontberings gepaard gegaan en veroorsaak dat, amper soos in die heel vroegste kerke, liturgie weer in die huise beoefen is. Die huisvader het tydens huisgodsdiens (veral Sondagmôrens) die gangbare liturgie van 'n kerkdiens gevolg en aangepas om sy gesin in staat te stel om God te ontmoet.

By die stigting van die eerste Gereforneerde kerke in die Transvaal, die OVS en Kaapkolonie in 1859/60 speel verandering van tradisionele liturgie sonder Skriftuurlike verantwoording, veral met betrekking tot die kerklied, 'n bepalende rol. Hoe 'n mens ook al na die sogenaande Gesangestryd kyk (Spoelstra, 1991), het die verandering van liturgie verantwoording vir die een party en lydelike verset om die verandering te aanvaar vir die ander party kerklike gemeenskap en formele kerkverband in gedrang gebring. Die GKSA verbind uit die staanspoor die uitnodiging tot en die behoefte aan kerklike eenheid met eenheid in die liturgie (GKSA, 1862: ant 12; Postına, 1905:124, 143, 188 e.v; Spoelstra, 1963:176, 179-180). Dié mense het eenvoudig aanvaar dat hulle liturgie met dié van die Sinode van Dordrecht 1618/19 ooreenkom (GKSA, 1955:396), terwyl hulle geen behoefte aan 'nuwighede' gehad het nie (Spoelstra, 1963:23-29, 190 ens.).

Die verband tussen imnerlike geestelike verskuiwing en die behoefte aan liturgiese verandering van liturgie wat daaruit voortkom, is eintlik nog nooit ontleed nie. Die invoer van die bundel Evangeliese Gesange deur Partikuliere Sinodes in Nederland in 1807 word vanaf 1814 sonder beoordeling geleidelik in Kaapstad en Stellenbosch en daarna in die buitedistrikte nagevolg. Die eerste verskil daaroor tree in die Ring van Graaff Reinet in 1833 (kort voor die Groot Trek) na vore wanneer advies gevra word hoe om teen 'weieragtiges' op te tree

Skynbaar het die liturgiese orde wat ds. Postına gebruik het, nie veel verskil van dit waaraan mense hier gewoond was of van dit wat by ander Afrikaanse kerkgemeenskappe in gebruik was nie. Toe die Revivalbeweging ongeveer in 1857 die liberalisıne die stryd aansê, kom die behoefte aan liturgiese verandering weer na vore en bring Hallelujaliedere, Kinderkrans, bidure, Nagnaalbediening in die banke, die nalaat van Kategismusprediking, ensovoorts, liturgiese veranderinge mee. Verskille trek in die vorige eeu saam in liedere, gebede en seremonies wat m die diens gebruik word en me op die orde (opeenvolging van liturgie) in die diens nie (Spoelstra, 1963:63, 118, 158, 161; Oberholster, 1956:120-189). 
'n Interessante maar moeilike vraag om te beantwoord is: Hoe het die mense die liturgie by ' $n$ 'kerkdiens' in die vorige eeu verstaan en beleef' Op grond van navorsing (Spoelstra, 1963:22-27) en die waarneming van die kerkbywoningspatroon voor 1940 is ek oortuig dat sporadiese kerkbesoek tot ongeveer 1940 te los van die daaglikse en deurlopende godsdiens beskou is. Voor 1940 het plaasmense in die suid-westelike Vrystaat hoogstens een maal in ses weke kerkdienste bygewoon en het sporadiese kerkbesoek (moontlik selfs minder as vier keer per jaar, vgl. I Sam 2:19) aan die kerksentrum met die oog op bediening van die doop en Nagmaal plaasgevind. Die sporadiese bywoning van 'n kerkdiens by die kerksentrum het die daaglikse, en veral die Sondagse ontmoeting met en aanbidding van God in die huisgodsdiens verleng en 'n hoogtepunt gevonn. Die huisgodsdiens (veral Sondae) of die laergodsdiens wat plaasgevind het by geleenthede waar in groepe getrek is, het ' $n$ vereenvoudigde orde van 'n kerkdiens gevolg. Namate perdekarre en ossewaens deur motors vervang is, verstedeliking plaasgevind het en eredienste oor die radio uitgesaai is waar preke gehoor kon word, is op kerkbesoek aangedring en het selfwerksaamheid in huisgodsdiens verval

Vandag word die liturgie van die eerste Christene in die huise weer hoog aangeslaan (Burkhart, 1982:107) en is dit selfs 'n ope vraag of die ontstaan en bestaan van massale 'gemeentes' werklik godsdıens kommunikeer. Kortom, nadruk op 'erediensbywoning' het die werklike beoefening van godsdiens in 'n hus (huisgodsdiens) met die orde van psalm, Skriflees, gebed, preeklees, gebed en psalm in onbruik laat raak. Gepaardgaande daarmee het die sogenaamde erediensliturgie (die groter, dikwels massale groep) olider die soeklig gekom, terwyl die pendulum vandag weer na die kleingroep swaai

Die aksent in die GKSA het na 1948 toenemend op institusionalisering begin val. Sporadiese 'kerkbesoek' is skerp veroordeel ongeag die vraag of gereelde 'huisgodsdiens' onderhou word. Veral emigrante uit die digbevolkte Nederland het die patroon van sesweeklikse kerkbesoek onder Afrikaanse plattelanders vreemd gevind. In amptelike stukke word gereelde 'godsdiensoefeninge' van die plaasmense nie in verband met die gemeente gebring nie, maar as 'n losstaande aktiwiteit van 'lidmate' beskou. Die dominee se weeklikse prediking moes opgesoek word. Waar die huislike liturgie vroeër vonnlike 'kerkbesoek' uitgeskakel en van periodieke besoeke aan Woord- en sakramentbediening 'n liturgiese hoogtepunt gemaak het (ontmoetinge met God en met mekaar), is godsdiens en liturgie steeds meer geobjektiveer en op 'n 'erediens' geprojekteer.

Die opkoms van die formele en omstrede idee van eredienste (vgl. Spoelstra, 1994) het die huisgodsdiens as liturgie van die gesin verplaas en gedevalueer. In gemeentes is sogenaamde 'ouderling-' of 'leesdienste' al meer vermy. 'n Diens sonder 'n predikant wat preek, is nie meer as erediens beskou nie en predikante het feitlik 'n monopolie verwerf om waar ook al in Woord en gebed voor te gaan. Die stem van een na die ander huisvader oor die Bybel, preekboek of Kerkhlad 
en wat vir sy gesin, kerk en volk in gebed voorgaan, het stil geword. Trouens die begrip voorgaan as liturgiese handeling het self begin uitsterf. Vandag word probeer (dikwels met 'n beroep op 'gawes') on weer iets hiervan op dreef te kry. 'n Rede waarom talle kerke nie meer deurknede 'ouderlinge' kry nie, is moontlik gelee in die feit dat die huislike aktiwiteite van die vaders in liturgie en kategese verdwyn het. Dit mag vandag bydra tot die aandrang on 'vroue' as ouderlinge te bekom.

\subsection{Besinning oor liturgiese orde in 1927}

Die teologie van Nederland het voor 1950 in Suid-Afrika baie invloed uitgeoefen, onder andere op grond van Abraham Kuyper se groot werk, Onze ceredienst, wat in 1911 gepubliseer is. In 1920 het die GKN 'n kommissie benoem wat in 1923 bepaalde voorstelle gedoen het wat die Sinode mie aanvaar het nie (Van Rongen, 1990:137).

Die kerkraad van Middelburg Kaap vra die Sinode van die GKSA in 1924 "om te adviseer aangaande die eenheid van die liturgiese orde" (GKSA, 1924:38). Die presiese aanleiding vir die versoek is nie duidelik nie. Op die Sinode is dr H.H. Kuyper teenwoordig, maar dit skyn asof met dié versoek eenvormigheid gevra is. Die kommissierapport en voorstelle in die Sinode vall 1927 (33-35, 79-81) dui ook enigsins daarop dat eenvonigheid enersyds en andersyds die behoefte aan liturgiese besinning vir die liturgie eerder as die orde gevra het (moontlik weens kontak met die 'jongeren' in Nederland).

Die Deputate gee in lutle rapport van 1927 waarskynlik hoofsaaklik die tradisionele orde weer - die orde van die votum af tot en met die psalm na die Wet en dui die orde verder aan as Skriflesing, gebed (lang gebed), psalmgesang met die oog op Woordbediening, preek, dankgebed, psalıngesang en seën. Die kollekte hoort by die erediens, maar dit word aan elke kerkraad oorgelaat om die plek daarvan te bepaal. Kollektes is tradisioneel by die deure opgeneem. Sommige mense het egter in daardie tyd gemeen dat kollektes prinsipieel in die 'erediens' tuishoort en kollektes iewers tussen die votum en seen verpligtend is. Die Sinode van 1961 wou egter nie so ver gaan nie (GKSA, 1961:389 e.v.). Die aandag vir die kollekte hang weer saam met nuwe belangstelling wat in die tyd vir 'barmhartigheidsdiens' ontstaan het. Unsprake van smodes met die oog op eenvormighend in kerkverband het destyds swaar geweeg.

Tweedens het die liggaamshouding by die psalms aandag gemet. Sommige mense wou van staande sing 'n reël maak omdat sodoende beter gesing kan word (vgl. GKSA, 1924, an. 111). Die aksent val dus op die feit van sing en nie waarom en wat gesing word nie. Liggaamisoal (soos sit of staan) is dus me liturgies vertolk nie (vgl. daanteenoor Burklart, 1982:23 e.v.) Indien staande sing by 'n lof- of 
danklied pas, sou kniel of selfs sit tog beter pas waar skuld bely of die lig van die Gees op die Skriflees of preek singend afgebid word

Derdens sê die Sinode dat afkondigings ınet die oog op die "meeste stigting" voor die diens gedoen moet word. Daaruit kan ons aflei dat sommige ampsdraers se liturgiese besef so swak was dat hulle sommer allerlei afkondigings gedurende die diens gemaak het en sodoende die aanbiddingskarakter van die liturgie geskaad het.

Die behoefte aan groter liturgiese verantwoording, moontlik as gevolg van wat in Nederland gebeur het, blyk uit 'n voorstel wat afgestemn word, maar baie sinvolle liturgiese insigte openbaar. Die 'môrediens' word na die lofpsalm in 'versoeningsdiens, diens van die Woord en dankdiens' onderskei. Met hierdie ordening tree $\sin$ vir gerigte liturgiese hoofmomente binne die diens as gelıeel na vore terwyl die Deputate net 'n 'liturgiese' orde vir 'n preekdiens anbeveel. Die liturgiese verantwoording en insig in dié onsuksesvolle voorstel word nog duideliker wanneer die 'versoeningsdiens' op sy beurt in ses liturgiese handelinge onderskei word: die lees van die Wet, sing van die berynde Wet of 'n boetpsalm, 'n algemene gebed (met skuldbelydenis), psalm vir 'absolusie' en geloofsbelydenis. Die voorstel het die diens van die Woord as Skriflesing, psalingesang met die oog op die Woord en 'n preek onderskei. Die dankdrens het vir die voorstellers weer dankgebed, dankpsalm, seĕı en kollekte ingehou. Kernbegrippe soos versoening, verkondiging en dank on die diens te tipeer en nie net liturgiese orde te reël nie, getuig van 'n begrip vir motief in litur oiese handelinge. Die terminologie soos psalm vir absolusie na die Wet en versoenmgsdiens. (GKSA, 1927:33) openbaar ongetwyfeld 'n dieper liturgiese begrip as die besluit van die Sinode van 1927 wat die voorstel afwys en net die bekende liturgiese orde vasstel.

Die karige gegewens dui veral daarop dat sommige mense in 1927 die Wet voor die Belydenis (soos Kuyper, 1911) wou lees. Die voorstel wat liturgies die swakste oorkom, wou die lang gebed op die psalm na die Wet laat volg en daana nog 'n psalm invoeg sodat die preek direk op die Skriflesing kon volg. Hierdie voorstel verraai klaarblyklik invloed van die Aufklärung wat die preek hoog aarslaan omdat mense daaruit leer. Wanneer psalms as gebede van die gemeente beskou word en nie bloot as gemeentesang wat 'n 'erediens' afwissel mie, hou hierdie voorstel 'n toutologie van drie opeenvolgende gebede in: daar word naamlik singend gebid, gebid en weer singend gebid. Verder staan hierdie voorstel onverskillig teenoor selfstandige Skriflesing waarin God met die gemeente praat, ondat Skriflees slegs met die oog op die preek plaasvind. Die Sinode van 1927 het hierdie voorstel afgewys, maar talle gemeentes in die GKSA het na die Sinode van 1985 tog die lang gebed net na die psalın wat op die Wet volg, geplaas omdat die Skriflesing volgens hulle met die oog op die preek moet geskied Selfstandige Skriflesing het daannee verdwyn, terwyl dit in talle Lutherse en ander kerke nog behou word. 
Die ouderlinge het klaarblyklik in 1927 nie die verskil onder die predikante oor liturgie begryp nie. Twee ouderlinge, Henning, (vader en seun?) het voorgestel om by die bekende orde wat die Deputate aanbeveel het te bly en "uitvoering daarvan (word) gelaat in die vryheid van elke kerkraad" (GKSA, 1927:34). Opvallend genoeg word die term erediens nie in 1927 gebruik nie.

Die liturgiese besef kom wel na vore waar die Sinode van 1927 begrippe soos loof en dank aan die psalm verbind, maar die liturgiese besef verswak wanneer dankgehed en dankpsalm naas mekaar geplaas word asof bid en psalmsing verskillende liturgiese funksies moet vervul. 'Sang' was skynbaar nie as bid of met God praat beleef nie, maar moes 'n eie liturgiese rol vervul omdat 'gesing' is. Die vraag is of die musiek in hierdie opsig kommunikasie moes daarstel. Die Sinode van 1927 oortuig dus mie dat die liturgie as sodanig sinvol deurgrond is nie.

\subsection{Liturgiese orde van die Sinode van 1955}

Die kerke van Suid-Transvaal vra "met die oog op groter eenheid" en on "eenvonmigheid te bewaar" dat die Sinode van 1952 "die saak van liturgie ... weereens ... in oënskou" moet neem (GKSA, 1952:290 e.v.). Die voorstel is vaag, stel niks voor me maar toon log dat daar iets van 'n onbehae met die liturgie aangevoel was. Hierdie onbehae hang moontlik saam met aspekte wat reeds in 1927 na vore gekom het. Op die Sinode van 1955 waar oor die liturgie gerapporteer word, was daar heelwat drukte oor vrae soos of belydenis van geloof staande gedoen, 'n psalm na die belydenis gesing, kollekte binne die diens opgeneem en vir elke psalın opgestaan moes word 'n Mens kan sê dat die aandag op die vormlike in die liturgie en nie $m$ die sin van die handeling saangetrek het nie

Die rapport het beweer dat die opdrag onduidelik was (GKSA, 1955:395-406) en gevolglik sluit dit in hoofsaak aan by die orde wat in 1927 gefonmuleer is. Die rapport beklemtoon nietemin die noodsaaklikleid dat "eenvonmigheid in dieselfde kerkverband" met 'n "verhewe en besielende liturgiese orde" moet heers en praat vir die cerste keer van 'n "erediens" as 'in fenomeen op sigself. Die erediens word gedefinieer as 'n samekoms wat bedoel is on God te verheerlik, die "vergaderde gelowiges te stig" en om "gemeenskap van die heiliges" te beofen.

Die Sinode van 1955 konstalcer 'n gebrek aan "aktiwiteit van die gemeente" as gevolg van min begrip vir die liturgie. In hierdie opsig tree dus dieselfde problem na vore as wat Beaudin in 1907 by Rome geïdentifiseer het (vgl. Lamberts, 1992:235 e.v.). Die rede vir die probleem word egter nie in die liturgie nie, maar In die begrip vir die liturgle gesock. Om "meer liturgiese besef by die gemeente" aan te kweek verskyn 'n publikasie Kom in sy voorhowe (Jooste, 1957). Hoewel daanta gestreef word om die gemeente aktief te betrek, word die diens tog grootliks in die hande van die 'liturg' gelaat wat beurtelings namens God en 
namens die volk optree (GKSA, 1955:401). Die aktiwiteit van die gemeente bestaan in meelewing met wat die 'liturg' doen. Die gemeente (leiros) doen (ergon) baie min. Direkte aktiwiteit kom feitlik net na vore in opstaan by die geloofsbelydenis en psalmsang (en natuurlik wanneer gedoop of na die Nagmaaltafel gegaan word). Die deputate vra (sonder liturgiese motivering) dat "meer gemeentesang" moet plaasvind en meer as een vers per keer 'gesing' moet word. Uit die behoefte aan 'meer sing' word oorweeg om onder andere na die geloofsbelydenis 'n psalm in te voeg. Die Sinode wil nie dat die Wet voor die geloofsbelydenis gelees word nie en 'n vraag of kommunikante tydens Nagmaal aan die tafel moet bly sit totdat 'n psalmvers klaar gesing is, laat die Sinode aan die vryheid van die kerkrade oor (GKSA, 1955:397, 405).

In werklikheid lewer die Sinode van 1955 niks nunts nie. Die oplossing om meer aktiwiteit te soek in opstaan en meer dikwels te sing, is eintlik bloot fonmele maatreëls en nie liturgies-funksioneel verantwoord nie. Die vraag of die psalms as gebede of bloot as liedere en musikale uiting beskou word, is nie gevra nie (vgl. byvoorbeeld Steiger, 1992/3:7, Van Rongen, 1990:64, 138; Runia, 1991:5, Psalms as tehillim lofprysing ens.). In sy geheel beskou, kry 'n mens die indruk dat die Sinode op losstaande liturgiese vonne van 'n 'erediens' toespits en nie die liturgie met die oog op 'n ontmoeting met God beoordeel nie Die uitgangspunt is klaarblyklik dat twee dienste plaasvind en dat 'n bepaalde 'orde' elke diens outomaties konstitueer (vgl. Spoelstra, 1994:39 e.v).

\subsection{Die soeke na groter liturgiese variasic in $\mathbf{1 9 8 5}$}

Die Suidelike Partikuliere Sinode versoek die Sinode van 1982 on die tweede erediens soos die eerste erediens met geloofsbelydenis en afkondiging van die Wet te laat plaasvind en on groter variasie in liturgiese formules uit die Skrif ten opsigte van die groetseën, die voorlees van die Wet en die slotseën toe te laat. Hierdie versoek is gerig met die oog op mense wat net een diens bywoon. Die Sinode antwoord nie op die bepaalde versoeke nie, maar verwys weer soos in 1952 die "hele saak van liturgie" vir studie om op die volgende Sinode daaroor te handel (GKSA, 1982:511 e.v.). Hierdie prosedure bots met goeie orde omdat die versoeke nie deeglik ontleed en vir die deputate duidelik aangedui is nie (kyk artt. $31,33,46 \mathrm{KO}$ ).

Die studierapport lig die Sinode van 1985 uitvoerig in oor tempel- en sinagogedienste en oor liturgieê by verskillende Refonnatore. Die rapport sê egter baie ınin of niks oor die missa calechumenomu en mussa fidelium in die vroeë kerke (vgl. Van der Leeuw, 1946:133-145) en oor die liturgie in die missale romantum waarby veral Bucer en Calvyn aansluit (Brienen, 1987:121, 137, 147, 264; Bamard, 1981:305). Daarteenoor het Calvyn juis vir hervonning altyd na die gewoonte van die ou kerke gevra. 
Die rapport mis gevolglik die verskil tussen Zwingli en Calvyn ten opsigte van liturgie en gaan verkeerdelik daarvan uit dat Calvyn - soos Zwingli - aparte Woord (pronaus) en spesiale Nagınaaldienste voorgestaan het (GKSA, 1985:398405). Die verskil tussen wat Calvyn begeer en wat die owerlede hom toegelaat het (Brienen, 1987:138), is ook nie ontleed nie.

Die Rapport gee kursories inligting oor hoe die liturgie, wat hoofsaaklik van a Lasco, Micron en Zwingli afkomstig was, in Nederland vermink geraak het. By Dordrecht 1578 het die kerke nog aan selfstandige 'troosspreuke' uit die Skrif en gebede voor die preek vasgelıou - 'n gebruik wat aan die skuldbelydenıs en abso. Iusie by Calvyn herinner. By Middelburg (1581) oordeel hulle egter dat die "bindynghe ende ontbindynghe der zonde ghenoechsaem inde predicatie des woorts geschiedet" sodat 'n liturgiese fonmulier vir skuldbelydenis en absolusie nie nodig geag word me (GKSA, 1985:403). In Nederland het die gemeentelike liturgie in die preck opgegaan. Ons erf unt Nederland die swakste liturgie uit die Reformasie, sodat Van de Pol (1931:49 e.v. 1986:202) en Van der Leeuw (1946 22, 153 e.v.) met waarderende oe na die Anglikaanse liturgie kyk. Daarin is van die oudste liturgiese vorme en handelinge soos kniel (vgl. Kuyper, 191 1:37, e.v., 230 e.v.) bewaar - liturgiese vorme wanteen die Puriteine oordrewe besware gekoester het.

Die Sinode definieer die erediens as 'n omvattende ontmoeting tussen God en sy gemeente (GKSA, 1985:405-410) maar vra nie of hierdie pragtige aanspraak elke keer waar is nie (vgl. Spoelstra, 1994). Die Sinode neem aan dat wanneer die liturgiese vonne en inhoud wat die Sinode met votum, aanvangseën, gemeentesang, geloofsbelydenis, wet, Skriflesing, gebede, Skriflesing en prediking, barmhartigheidsdiens en slotseën aandui, deurloop is, het daar outomaties 'n erediens plaasgevind. lirediens word dus met die algehele liturgiese orde en met 'n objektiewe gebeurtenis geidentifiseer. Daarteenoor val dit op dat self Roomse teoloe vandag beklemtoon dat "werkelijke deelneming" 'n voorwaarde vir liturgiese "spiritualiteit" en 'n ontmoeting met God is (Waaijman, 1992:235-237).

Wanneer die begrip eredicns in 1985 as vertrekpunt geneem word om 'liturgiese grondlyne' vas te stel het die klem effens verskuif van die vertrekpunt in 1927 Moontlik bring die verskuiwing nuwe woorde soos aamvangseën. harmhartigheidsdiens en slotseèn vir die eerste keer in sinodale handelinge na vore omdat die 'erediens' icts op sigself is wat 'n aanvang neem en 'n slot moet hè; gevolglik moet ook die banmlıarigheidsdiens bimne die aanvang- en slotpole plaasvind. Die probleem is egter dat die bannhartigheidsdiens eers werklik plaasvind wanneer die gemeente se gawe die mens in nood bereik (Heid. Kat. S. 38).

Wanneer die Sinode van 1985 die rapport belsandel, word enkele voorskrifte ten opsigte van die aamvangseën gereglementeer, die gebruik van ander ekumeniese simbole vir die geloofsbelydenis gereël, Deuteroniun 5 as alternatief vir die Wet en 1 Petrus 5:10, 11 as altenatief vir die seen aangedui. Die wegstuurformule by 
die 'slotseën' word opsioneel gelaat. Die Sinode spreek hom oor talle aanbevelings en motiveringe nie uit nie en wys sonder motivering 'meervoudige Skriflesinge' af. Die Sinode laat dit egter aan die vryheid van die kerke oor om 'n algemene lang gebed voor die Skriflesing te doen on sodoende die Skriflesing aan die preek te verbind (GKSA, 1985:410-420). Die motiewe vir hierdie advies ontbreek sodat die manier van doen nie van diepgaande liturgiese besef getuig nie.

Die Sinode van 1985 bly dus eintlik by die liturgiese orde van 1927. Sang en gebed word nog steeds naas mekaar geplaas asof daar 'n onderskeid in die liturgiese funksie van sang en gebed is. Alhoewel die deputate die erediens as ontmoeting met gesprek motiveer, benader die Sinode 'sang' nie in die eerste plek as mediun vir kommunikasie of gesprek in die ontmoeting met God nie; dit skyn asof sang op 'n ander manier as gebed eer aan God moet gee (GKSA, 424 e.v.). In die geheel lyk dit asof die Sinode van 1985 nie van probleme met die bestaande liturgie oortuig was nie, reglementering wou vermy en nie deur 'n swak gemotiveerde deputaterapport op sleeptou geneem wou word nie. In die afwesigheid van grondige liturgiese argumentasie het die Sinode "die orde van gebed, Skriflesing en prediking aan die vryheid van die plaaslike kerk oorgelaat" (GKSA, 417) sonder on daanmee 'n groen lig vir allerlei willekeurige eksperimentering met die liturgie te gee

\subsection{Liturgieprobleme vir die GKS:}

\subsection{Twee eredienste kort na mekaar}

Müller (1987:34) stel dit dat die "op skrifgestelde orde van 'n diens ... onontbeerlik [is]" en met die "partituur van 'n orkesuitvoering" vergelyk kan word Die ontınoeting van God en sy volk kan egter nie in die "drukletters" vasgevang word nie (Müller, 1987:34). Die nakom van 'n liturgiese orde of 'n opeenvolging van sogenaamde elemente van 'n erediens stel dus nie outomaties 'n erediens daar nie Twee preekdienste kort na mekaar kan moeilik gemotiveer word as noodsaaklik vir die ontmoeting met God, vir godsdiens en die betoon van die dankbaarheid wat ons aan God vir sy kom na ons in Woord en Gees verskuldig is. Die GKSA ondervind tradisioneel probleme met die bywoning van veral die tweede erediens op 'n Sondag. Toenemend word 'n oplossing gesoek deur 'twee eredienste' ongeveer 'n halfuur na mekaar vir dieselfde mense op dieselfde plek met baie dieselfde liturgie aan te bied Die rede is waarskynlik ook dat omstandighede net oggenddiens(te) moontlik maak. Dié probleem het egter baie kante. So kan byvoorbeeld gevra word: Waarom moet dieselfde mense twee keer kort na mekaar saamkom on die Here te ontmoet? Was daar fout met of onvolledigheid in die eerste ontmoeting dat dit herhaal moet word? Waarom moet die gemeente wat weggestuur was deur die seën aan die einde van die eerste samekoms, kon daama weer dieselfde liturgie deurloop - met kollekte en al? Is die tweede samekoms nie ook iets van 'n alternatiewe samekoms wat ook mense kan bedien wat nie die 
eerste diens kon bywoon nie? Kortom, is twee eredienste verpligtend vir dieselfde mense of het gemeentes behoefte aan altematiewe dienste in die huidige situasie, al is die bywoning van die tweede hoe klein? Die antwoord op dergelike vrae gaan ekklesiologies dieper as die liturgiese probleme. Die probleme word daar gelaat en slegs liturgies na die moontlikheid van twee dienste kort na mekaar gekyk.

In twee dienste kort na mekaar herhaal dieselfde mense gewoonlik kort na mekaar dieselfde liturgie: die groetseën, voor- en na-gebed, twee preke, twee kollektes en die seën word herhaal. 'n Baie belangrike liturgiese vraag kom op grond van hierdie gebruik na vore: Wat is die sin van die eeu-oue Skriftuurlike seën aan die einde van die diens uit Numeri 6 of 2 Korintiërs 13 wat die gemeente wegstuur (vgl. "ontvang die seën van die Here en gaan in vrede") as veronderstel word dat die gemeente nic moet weggaan nic, maar na 'n kort pouse moet terugkeer om feitlik dieselfde liturgie te herlaal? Rym die praktyk met Sondag 38 (Heid. Kat.) of NGB 28? Kontom, is die motief vir hierdie 'twee eredienste' werklik om die Here te onmmo't of geskied dit dalk om die predikam geleentheid vir onderng deur middel van wee preke te gee? Dui die twee 'dienste' kort na mekaar, al is dit hoe goed bedoel, nie op formalisme rondom iwee eredienste, 'n lang geskiedenis van probleme met die tweede diens en die erosie van liturgiese besef en belewing nie? Om te antwoord dal die gemeente ree preke moet hoor. mag skolasties in orde wees, maar kan nie liturgies verantwoord word wanneer die erediens sy sin vind in dic onmmetmg met forl ne.

In buitengewone omstandighede mag verskillende motiewe en behoeftes opeenvolgende ontmoetinge met God laat plaasvind. Die vraag is egter of twee eredienste kort na mekaar deur die gewone en gereelde betoning van dankbaarheid (Sondag 38 Heid. Kat.) verplig word. Ontstaan die situasie van twee eredienste kort na mekaar nie uit die voorveronderstelling dat in erediens 'n objektiewe gebeure volgens ' $n$ bepaalde agenda is wat 'n ontmoeting met meer preke meebring, maar nie vanuit 'n onmmocmug met (iod en mekaar gemotiveer word nie Die 'twee eredienste' het uit 'n bepaalde motief met betrekking tot omraming en heiliging van die Sondagviering voortgespruit - 'n motief wat kwalik op twee dienste kon na mekar toegepas kan word.

\subsubsection{Willekeur in liturgiese orde}

Brink tabelleer grootskaalse liturgiese willekeur in die CRC van die VSA (Brink, 1991). Daarteenoor val die noukeurige voorskriftelikheid van die liturgie in die Ou Testament op. Die Here lesus stel "gees en waarheid" (Jol, 4:23) as nonn vir die Nuwe-Testamentiese liturgie. Die Nuwe Testament sè juis ten opsigte van liturgie dat alles ordelik moet geskied en gee bepaalde eenvoudige riglyne (I Kor. 14:40); gevolglik moet kerke in kerkverband liturgiese orde volgens bepaalde norne met mekaar reël (vgl Barnard, 1981 486, 491 e.v., 500-504). Tereg sè De 
Klerk (1987:3 e.v.) dat die sinodale handelinge van die GKSA die motivering oor liturgie mis.

Müller (1987) sè dat die NG Kerk los elemente van die 'erediens' onverantwoord verander en hanteer en daarom in tradisionalisme, ritualisme en wettisisme vasgeval het. Die omgang van die GKSA met die liturgie maak 'n fonnele indruk. Indien van die begrip liturgie in plaas van erediens uitgegaan word, mag die aksent dalk beter op die dinamiese godsdiens of liturgie as doelgerigte gebeure val. Miskien verklaar liturgie as godsdiens waarom 'n Australiër na 'n besoek aan 'n swart kerk in Suid-Afrika sê: "It was an indication that warnth and vitality can go together with a more traditional style of worship" (De Waardt, 1993:3).

\section{Liturgiese handelinge nader bekyk}

\subsection{Uitgangspunt}

Calvyn het geglo dat die tweede gebod reêl hoe God op die regte wyse vereer moet word (vgl. Brienen, 1987:148). Vonngewing van die liturgie raak "die allerdiepste dinge van die mens, dit raak die kerk, sy belydenis, ja die hele teologie ... Agter elke vonn van erediens staan 'n duidelik onderskcibare teologie van die erediens". Die erediens is nie self belydenis nie, maar spreek die taal van die belydenis (Bamard, 1981:486, 491; vgl. art. $32 \mathrm{NGB}$ ).

Die werklike agtergrond vir en historiese verantwoording van die liturgie van die GKSA is nog nie beskryf nie. Die liturgie kan maklik aan Nederland verbind word. Die Nederlandse liturgie word weer tradisioneel aan Cavyn verbind wat dit van Zwingli se pronaus (leerdiens) sou gekry het. Die navorsing van Brienen toon egter aan dat Farel in Genéve die liturgie van Zwingli ingevoer het en dat Calvyn daarvan verskil het. Hy het byvoorbeeld nie 'n weeklikse pronaus en kwartaallikse Nagmaalsdiens voorgestaan nie (Brienen, 1987:133 e.v.).

Die leer of preekdiens (pronaus) van Zwingli wat aan die missa calechemenorum herinner, het Surgant kort voor die Refonnasie weer beklemtoon (Van Rongen, 1990:90 e.v.). Zwingli het sy opvatting waarskynlik van die Nederlander Hoen gekry, maar raak sodoende met liturgie bekend wat in die oostelike en noordoostelike Nederlande in gebruik was (Tanis, 1991:313, 319 e.v.). Die humanisme het in Nederland met Gansfort en Erasmus die Reformasie voorberei en gerig op die leerdiens en die preek. Nederlanders erken dat hulle tradisie op die preek toespits terwyl De Jongh tereg sê: "De kerk kent geen toeschouwers. In een kerkdienst is geen publiek. Iedereen doet mee" (De Jongh, 1993:15). Wanneer op die preek toegespits word, doen elkeen nie so maklik mee nie.

Dit is moeilik om vas te stel hoe die liturgie gelyk het wat van Nederland na die Kaap gekom het. "Het onderzoek naar de liturgische praktijk in een bepaalde 
periode van de geschiedenis is deurgaans een moeilike zaak ... Het beeld ... is veelal fragmentarisch" (De Jongh, 1990:11). Hoewel na onderlinge eenheid in eenvormigheid gestreef is, het tot diep in die 18de eeu baie regionale verskille in Nederland voorgekom (De Jongh, 1991:16-21). Die predikant was in Nederland grootliks "outeur van alle liturgie" (De Jong, 1991).

Uit die versoek op die Sinode van 1924 en die rapport voor Sinode 1927 is dit duidelik dat predikante in die GKSA vir hulleself vryhede in die liturgie veroorloof het (bv. met aankondigings, ens.). Tog kan 'n mens ook aanneem op grond van die wyse waarop dit gebeur het dat die Sinode van 1927 die gangbare liturgie verwoord het.

\subsection{Votum en groetseën}

Die votum word die "openingsverklaring van die erediens" genoem om die nog losse opkoms tor 'n doelgerigte vergadering te orden (Van der Walt, 1982:18; Kuyper, 1911:179). Op die volum volg die groetseën (vgl. in vroee kerke die 'vredeskus'). Wie van 'groetseen' praat, beklemtoon diakoniologies die plek en funksie van die dienaar wat God geroep het on voor te gaan (Van der Leeuw, 1946:161; Deddens, 1981:37 e.v; Jonker, 1962:144; GKSA, 1955:396 e.v.). Die amptelike groet sluit aan by die aanhef in die Nuwe-Testamentiese briewe waar die gesant van God die gemeente met die 'groetseën' na sy Sender wys. Namnate die begrip erediens ekklesiologies vorn aangeneen het, het die idee van aanvangseën van 'n 'erediens' na vore gekom (GKSA, 1985:411 e.v.; Van der Walt, 1982:21-36, 66, vgl. egter o.a. Hendriks, 1983:83-92).

Die verskillende opvattings lei tot verskillende liturgiese gebare. Wie van 'n aanvangseën uitgaan, dring aan op die priesterlike seëngebaar met twee opgehewe anns soos by die 'slotseën' (vgl. GKSA, 1985.412, sonder motivering). Hierdie opvatting dupliseer en verswak liturgies die wegstuurseën. Die groetseën met een opgesteekte hand hou weer verband inet die sjalooın-groet in die sinagogekultus.

\subsection{Gemeentesang}

Die gerefonneerde liturgiek praat van gemeentesang (GKSA, 1985:412) waarin die idee van musick as 'n eie kommnunikasievorm sterk na vore tree (vgl. Strydom, 1987:47 e.v., GKSA, 1973:245-302; 1982:202-208). Gewoonlik word psalms aangekondig met 'die gemeente sing nou tot lof van God van psalın so en so'. Die gebruik van die werkwoord sing skep die indruk dat dit on die sing eerder as on die praat met God gaan. Die idee dat die musiek 'n eie funksie vervul, het veroorsaak dat Sinodes begin het on bepaalde melodieë op grond van hulle musiekwaarde voor te skryf (GKSA, 1952:291 e.v.; 1979:612). Waar die GKSA vir I6de-eeuse Geneefse musiek gekies het, sê The Banner (1992) van die CRC in die VSA weer: 
Few of us would insist that we use only the music that prevailed in Geneva's Calvinistic worship services. If we did, harmony in the church might be lost forever. But no one could argue against regaining Calvin's sense of awe in the presence of God.

Die vraag is of die musiek draer van en diensbaar aan die woorde is waarmee tot God en mekaar gepraat word en of die musiek self die aanbidding, verheerliking of dien van God moet uitdruk. In die Ou Testament het kore by die tempel, veral wanneer die volk nie daar was nie, voortdurende kommunikasie tussen Jahwe en die volk uitgebeeld. By die volksfeeste het die volk self met offers en liedere met Jahwe gekommunikeer (Trimp, 1983:83-86; vgl. Jonker, 1962:127).

Is die sang 'n item wat die 'erediens' afwissel? Eer die gemeente God met musiek soos die engele sodat gesê kan word: "Kirchenmusick ist praeludiun vitae aetemae" (Steiger, 1992/3: 180)? Al moet al ons doen en late oral en daarom ook ons musiek God eer en dien, moet die funksie van musiek in die ontmoeting met God bepaal word. Is Luther korrek dat die musiek (as sodanig) cvangelie verkondig, die Woord na die hart toe dra en blydskap as antwoord op die heil uitdruk (vgl. Steiger, 1992/3:177 e.v.)? Maak note die teks lewendig en kan preke gesing word? Indien wel, volg die vraag: Moet die gemeente met die woorde van die lied met God praat, ongeag hoe vals of musikaal swak die woorde gesing word of moet die sang ell gehalte daarvan God prys? Die woorde en nie die musiek nie bepaal of die gelowige in die psalm aanbid, bely, prys, smeek, of aanroep. In die Ou Testament is die woorde van Psalms kanoniek, maar nic die wysies nie (vgl. Pss. 45:1, 53:1, 57:1 elıs.). Die gebruik on strofes voor te lees en daana met sang te dupliseer, moet daarom sensitief gehanteer word (GKSA, 1955:404).

Calvyn se bewoë ervaring toe hy 'n gemeente in Strassburg vir die eerste keer hoor sing het (vgl. Heyns, 1903:114 e.v.) het aan die psalm 'n plek in sy liturgie gegee. In die Roomse Mis-liturgle het die priester psalms 'gesing' en die gemeente het toegekyk Calvyn het die psalm ut die priesterliturgie na die gemeente teruggebring sodat die gemeente daarmee direk met God en met mekaar in die erediens kon praat. Hy het daarom benadruk dat die meeste psalms gebede is (Brienen, 1987:114; Van Rongen, 1990:113 e.v., 124) Psalms is deur die eeue gelees, gebid, gesing en oordink (vgl. Hamink, 1992:274).

Sou die deursneegemeente vandag die psalm in die erediens nog as gebed, belydenis of praat met God ervaar? 'n Sinode (GKSA, 1955:396 e.v.) handhaaf tereg die gesprekskarakter wanneer gesê word dat "die gemeente moet begin om die Here te loof". Om daama te praat van 'n "gesang met die oog op Woordbediening" dui nie die liturgiese funksie aan nie ondat dit hier gaan on 'n psahm as epıklese en gebed. Die Sinode van 1985 neem kemnis dat die funksie van die lied op 'n gesprek met God neerkom en dat dit aan die "gesprekskarakter van die erediens" moet voldoen (GKSA, 1985:412 e.v.). Waarom sou die Sinode hiervan 
net kennis geneem het en die korrekte stelling nie aanvaar of goedgekeur het nie? Psalms (soos dankgebede) moet respons op die ontmoeting en Woord wees (Barnard, 1981:191). Al 150 Psalms is daarom nie ewe geskik vir die 'erediens' nie.

Gelowiges kan die Woord wat God tot hulle rig buite die erediens sing en vir mekaar en vir die wêreld van die groot dade van God in 'n lied vertel, maar wanneer hulle God in 'n 'erediens' ontmoet en met Hom praat, sal die psalm liturgies op bid tot, bely voor of verheerlik van God gerig wees. Die gemeente gebruik daarvoor die liriek van geïnspireerde digters, profete of apostels uit die Skrif (vgl. Van der Leeuw, 1946:168-170; Dressel, 1988:3, 6 e.v.). Die lied in die erediens moet op kommunikasie met Hom gerig wees (GKSA, 1985:412). Hierdie beginsel sluit solosang, koorsang, of verkondiging van die Woord as gesingde preke in die 'crediens' uit.

Dit is opvallend dat psalms wat direk met God praat, tereg in die erediens voorkeur kry. Calvyn het ook eers net dertien psalms $(25,36,46,91,138$ ens.) geselekteer (vgl. Banard, 1981:317). Die gemeente behoon die lied in die liturgie baie meer spontaan aan te hef (Van der Leeuw, 1946:162). Die Sinode van 1955 het met goeie reg oorweeg om 'n psalm spontaan na die Wet te laat sing (GKSA, 1955:403). Indien die liturgie begryp word, kan spontane handelinge die sin van die liturgie verhoog. Die huidige psalm na die Wet en die wyse waarop dit aangekondig word, funksioneer nie meer duidelik as skuldbelydenis of genadeverkondiging nie en word net as "toepaslike verse" by die Wet aangedui (GKSA, 1955:396, 404) of glad nie meer genoem nie (GKSA, 1985:414). Die funksie van die psalms in die liturgie is volgens genoemde interpretasie nie deeglik verantwoord nie.

\subsection{Die geloofsbelydenis}

Die plek van die geloofsbelyden set in die vroeë kerke by die doopliturgie geval. Volwassedoop het na die belydenis van geloof geskied ondat die geloofgemeenskap vasgestel moes word voordat Nagmaalsgemeenskap kon plaasvind. Teen die vyfde eeu het die Oosterse (Griekse) Kerk die credo by die liturgie van die missa fidelium ingevoer (Van der Leeuw, 1946:141, 173 e.v.). Die credo was die poon waardeur tot die eucharıstue (kommunie) oorgegaan is.

Die Nederlandse liturgie ondergaan verskillende invloede (vgl. Van der Leeuw, 1946:154 e.v). Johannes a Lasco, 'n 'slordige opvolger' van die Reformatore, het op 'n gebed met skuldbelydenis, die Wet en daana die credo by die missa fidelium laat volg. In die Franse liturgie sluit die credo die pronaus of amekommume af (Van der Leeuw, 1946:133 e.v.). In Strassburg vonn die credo deel van die Nagnnaalsfonnulier. Calvyn laat die credo sing net voor die instellingswoorde by die Nagmaal. In die Anglikaanse liturgie doen die gemeente na die 
Wet en Skriflesings staande die credo met belydenis (Van der Leeuw, 1946:145153; GKSA, 1985:402 e.v.). Die Nederlandse en Geneefse liturgie het onder invloed van Zwingli (vgl. Spoelstra, 1994) die gereelde preekdiens los van die Nagmaalsdiens benader. Daardeur kom die liturgiese funksie van die credo in gedrang.

Die GKSA plaas die geloofsbelydenis vroeg na die lofpsalm en voor die Wet (GKSA, 1955:396; 1985:404, 413). Deputate wou die gemeente meer 'aktief' betrek en het die sing van 'n spontane lied na die Geloofsbelydenis aanbeveel (GKSA, 1955:403); dit maak liturgies egter nie sin nie (Van der Walt, 1982:44). Die geloofsbelydenis sou beter saan gesing of hardop gesê kon word (GKSA, 1982:513 e.v; 1985:413 e.v.).

\subsection{Die Wet van die Here}

In die Ou Testament speel die Wet (Tora) wat die wil van God vir die lewe van sy verbondsvolk reël 'n groot rol (De Klerk, 1990:17); tog oefen die Joodse liturgie invloed uit. In die Clementynse liturgie het voorlesers in die diens die (Mis) van die kategumene uit die Wet, profete, Briewe en evangelies voorgelees (Stoop, 1992:3, 83). Die Dekaloog is wel in die sinagoges gelees, maar is waarskynlik nie in die vroegste Christelike liturgieë gebruik nie (Banard, 1981:544). Oor die plek van die Wet in die liturgie bestaan gevolglik verskil. Sommige laat 'n voorleser die Wet voorlees, ander bring dit in verband met die skuldbelydenis voor die preek en Calvyn laat sy beryming van die Wet aan die einde van die erediens, na die skuldbelydenis en genadeverkondiging as reël van dankbaarheid sing (Brienen, 1987:202)

Die Wet is kenbron van die sonde, reël van dankbaarheid en konstitueer die verbondsopset (De Klerk, 1990:19). Die Refonnasie ken die Wet as "tugmeester" tot Christus en daarom kan die Wet by die skuldbelydenis betrek word (Van der Leeuw, 1946:161; vgl. Heid. Kat. S. 2). Die GKSA plaas die lees van die Wet (Eks. 20 of Deut. 5) na die geloofsbelydenis, dit wil sê by die skuldbelydenis. Van der Leeuw meen dat die Nuwe-Testamentiese opsomming altyd na die Wet gelees moet word (1946:167; Van Rongen, 1990:61). Die skuldbelydenis as liturgiese handeling word in die sinodebesluite van die GKSA onderbelig. Daar word van 'sing' na die Wet gepraat, terwyl skuldbelydenis ook hardop soos by Calvyn in ' $n$ bepaalde fonmuliergebed gebid sou kon word. Op die skuldbelydenis sou 'n absolusie kon volg (vgl. Kuyper, 1911:217 e.v.).

\subsection{Die Skriflesing}

Die Skriflesing(s) is 'n ander probleemarea in die huidige liturgie, veral wanneer ons liturgies tussen die lees, hoor en preek van die Woord onderskei (Van der Walt, 1982:47). Van der Leeuw (1946:170) sê: 
De Schriftlezing in den eredienst is geen onderricht in de Heilige Schrift, geen catechesatie ... zij is verkondiging van Gods Woord. God spreekt tot de gemeente. Dat is niet een voorlezing, maar een gebeuren, een daad ... God treedt in het leven van de gemeente met zijn heilig Woord ... De Schriftlezing heeft dus een sakramenteel karakter ... Zij dient dan ook niet ter voorbereiding van de preek ... $\mathrm{Zij}$ is in wezen evangelie, blyde boodschap, proclamatie, dat God het koningschap heeft aanvaard.

Omdat Rome verkondiging verwaarloos het, wou Luther met die Woord opvoed. Die Lutherane reik nou nog 'n lectionary uit waarin 'n vaste program van Skriflesings volgens die kerklike jaar voorgeskryf word. Hierdie Skriflesings "can stand on their own without further clarification" (Beiritz, 1991:37-43; vgl. Barnard, 1981:562-564). Die Nederlandse kerke het egter by die Sinode van Dordrecht 1574 van die selfstandige Skriflesings in die liturgie begin afwyk en alle aandag op dic preck toegespits.

Die humanisme en intellektualisme het die preek in die liturgie oorspan ondat hulle geglo het dat onderrig of die meedeel van kennis, mense verander (Bamard, 1981:375). Die Woord word met die preek geidentifiseer en sentrum van die erediens gemaak (Noordmans, 1986.98, 134 e.v., 174-212). Die volk moet net lusster en hoor en hulle laat lei deur die prediker (vgl. GKSA, 1955-401-403) en die liturgie (letterlik volks-werk) kom op 'n vlak van lae aktiwiteit te staan. On na 'n kerkdiens te gaan om 'n preek te gaan hoor, maak van die kerkganger 'n toeskouer, self wanneer die preek hom diep raak (De Jong, 1993:15; vgl. De Klerk, 1987:190; Du Toit, 1977:29).

Die liturgie van die GKSA onderskel aanvanklik tussen Skriflesing en preek (GKSA, 1955:396). Die Sinode van 1985 wil nie meer 'n selfstandige Skriflesing voorskryf nie en laat toe dat die lang gebed vir alle nood vóór die Skriflesing gedoen word, sodat die mens God aanroep voordat God met hom gepraat het. Skriflesing word volledig aan die preek verbind (vgl. GKSA, 1985:415-418). De Klerk (1987:105, 115-134) wys op die Skriflesing as dié "saambindende faktor" in die erediens ell pleit tereg vir 'n "Inoontlike selfstandige plek" vir Skriflesing. Die koppeling van Skriflesing en die dominerende preek veroorsaak dat die sakrament van die doop soms voor enige Skriflesing bedien word, asof die sakrament aan die Woord voorafgaan. Die Skrif waarin God direk met sy volk praat, geniet tans nie duidelike liturgiese waardering nie, terwyl dit hoog aangeslaan moet word (vgl. Van der Walt, 1982:46). Skriflees en preek behoon in die lifurgie onaflanklik van mekaar elk "sy eie majesteitlike plek [te] beklee" (Van der Walt, 1982:48). 'n Selfstandige Skriflesing kan selfs help om Skrif met Skrif te vergelyk wanneer die teks vir die preek uit 'n eie Skriflesing kom. Die liturgie kan baat wanneer die gemeente na goedgekose Skriflesings uit die Ou Testament en Nuwe Testament volgens 'n vaste program luister, te meer waar Skriflees tuis selektief gedoen word of dalk heeltemal in onbruik raak (vg). Du Toit, 1977:17, Jooste, 1957:28, Van der l.eeuw, 1946:173). 


\subsection{Die preek}

Die preek dateer uit die vroegste Christelike kerke (Hand. 6:4; 2 Tim. 4:1-4;2 Pet. 1:19-21; 1 Kor. 14:1-9). Dit was skynbaar veral by die diens (die Mis) van die kategumene gebruik (Stoop, 1992:83). Die evangelie van die koninkryk moet verkondig word omdat Christus sy kerk daardeur opbou en regeer. Die preek bedien (net soos die Skriflesing) die sleutelmag (Heid. Kat. S. 31; De Klerk, 1987:187). Die preek in die samekoms en liturgie vall die gemeente is nie die enigste vorm van Woordverkondiging nie Die opdrag om die evangelie te verkondig (Matt. 28:19, Hand. 1:8, 1 Tim. 5:17, 2 Tiin. 4:2), geskied basies in kategese, huisbesoek en sendingprediking. Die vrug van die Woordverkondiging is juis liturgie waarin die gemeente hulle God ontmoet. In die liturgie moet die preek deel wees van die ontmoeting of gesprek tussen die Here en sy volk - 'n woord waarin God op 'n antwoord van die gemeente aandring (Barnard, 1981:564-566, Brienen, 1987:232, Spoelstra, 1989/12-116). Die preek is dus 'n belangrike, 'n selfstandige maar nie die moment in die liturgie nie. Die teenwoordigheid van die Vader en Christus in die Gees dien in die liturgiese ontmoeting (vgl. Barnard, 1981:416; Brienen, 1987:28 e.v.).

Noordmans sê dat die gemeente "altijd bijeen komt oın naar Gods Woord te luisteren". Hy (Noordınans, 1986:259 e.v.) vrees dat Van der Leeuw se aksent op liturgiese handelinge in 'sakramentsteologie' daartoe sal lei dat mense die preek wat die koninkryk verkondig, sal verruil vir Oosterse misterie (Noordmans, 1986: 326), vir menslike handeling, vir "één sacramentele liturgie" (Noordmans, 1986 : 331). Omdat die teologie van die kommkryk nog nie geskryf is nie (Noordmans, 1986:336) verwyt hy Van der Leeuw se aandag aan misterie. Noordınans vrees dat die gemeente vir die preek sal vlug in liturgiese landelinge.

Aan die ander kant bied 'n eensydige aksent op die preek vandag geen noemenswaardige liturgiese motivering nie. Selfs gelowiges kom on 'n preek en dikwels om 'n bepaalde persoon te hoor (Banard, 1981:371).

Die liturgie stel hoë vereistes aan die preek. 'n Preek wat in 'n redevoering of ' $n$ verhandeling oor 'n teks, leerstuk of 'n probleem verloop, is nie deel van die liturgie waarin die gemeente God ontmoet nie en daarom kan preke die grootste enkele oorsaak word vir die verval van die erediens en van kerkwees (vgl Runia, 1981; 1983; 1990; Brienen, 1987:9 e.v.). Die hoorder worstel immers met 'n natuurlike weerstand teen wat die Skrif sê, ondat liy twyfel of "we God werkelijk echt kunnen verstaan" en dus woed "een gevecht van de hoorders met de zaak van de Bijbel en met God. Het is een worsteling on de waarheid en oin het vinden van de juiste ricliting voor ons leven" (Dingemans, 1991:44). Die preek moet die 'geveg' allermins ' $n$ geveg met 'n onverstaanbare of vervelige prediker maak. 
Die voorskrifte vir die liturgie van die GKSA lê besondere nadruk op die preek. 'n Groot deel van die liturgie sentreer in die preek: om die preek word in die konsistorie en in die samekoms gebid, 'n psalm word voor en/of na die preek geplaas en dic dankgebed draai on die preek. Voeg die opsomming van die preek in die nuusbrief of bespreking van die preek na die diens daarby en 'n mens moet konkludeer dat die gerefonneerde liturgie oin die preek draai (vgl. De Jong, 1993). 'n Eensydige aksent op onderrig deur die predikant in die preek benadeel die liturgiese karakter van 'n erediens' (vgl. Du Toit, 1977:29, Spoelstra, 1994: 48 e.v.). Die preek is belangrik vir die aktuele ontmoeting met God, maar is ook die Achilleshiel waar die gemeente blote toeskoners of toehoorders kan word (vgl. De Jong, 1993).

\subsection{Die gebed(e)}

In die vroeë kerke is verskillende kon gebede (collecta, vgl. litanieë by Stoop, 1992), elkeen met 'n bepaalde liturgiese oogmerk gebid: skuldbelydenis, epiklese, lofprys, aanbidding of danksegging, intersessie en petisie. Die liturgiese fonnuliere by die GKSA in gebruik ken meer as een gebed, elkeen met ' $n$ bepaalde liturgiese plek en funksie by die sakramentsbediening. Calvyn plaas die lang gebed met danksegging, petisie en intersessie na die Woord van God gehoor is (Banard, 1981:568). Daarop het die gemeente met 'n 'amen' geantwoord (Banard, 1981:67; Van der Leeuw, 1946:136 e.v.). Die amen is later deur die voorganger oorgeneem, met die gevolg dat die amen sy betekenis van vastigheid en regskrag grootliks verloor het ondat dit van die gemeente weggeneem is (Trimp, 1983:95-98).

Sinodes van die GKSA $(1927,1955,1985)$ onderskei twee gebede, die sogenaamde lang gebed en dankgebed en die gebede word rondom die preek geplaas. In die liturgie van 1927 en 1955 kom die sogenaande 'lang gebed' na die 'Skriflesing'. In 1985 word vyheid gegee on die gebed voor die Skriflesing te plaas, sodat Skriflesing en preek 'n eenheid vorn - 'n ordening wat die aksent op die preekdiens (pronaus) plaas. Die gebede vonn 'n probleemarea in die liturgie en min liturgiese verantwoording word oor die gebedsdiens gegee. Daar kom ook praktiese vrae na vore oor hoe gebid word en of die gemeente kan saambid (Banard, 1987:57 e.v.; vgl De Klerk, 1987).

Om verskillende liturgiese monente soos skuldbelydenis, epiklese, voorbidding en petisie in een ommihusgehed aan die begin van 'n diens te bid, maak sinvolle onderskeiding tussen die verskillende bedes onmoontlik. Die omnibusgebed dra daartoe by dat die fonmuliergebede deur vry gebede vervang word (Bamard, 1981:372). 'n Verdere stremming is dat die liuidige fonnuliergebede agter in die Psalmboek allermins dinamies vertaal en op die situasie van vandag gerig is. Aan die ander kant het vaste fonmuliergebede soos die Onse Vader liturgiese waarde, omdat die gemeente onmiddellik saan kan bid 'n Vaste fonnuliergebed vir by- 
voorbeeld skuldbelydenis soos in Genéve sou dus oorweging verdien. Tegelyk sal krities gekyk moet word na die psalmgebed wat op die Wet volg, sodat dit doelgerigte gebed en nie bloot sing word nie.

Die gebedshouding varieer in die Ou Testament en daar is sprake van staan, kniel, na die grond buig, hande uitsteek, ensovoorts. Die liggaamstaal het gepas by die aard van die gebed. Die Nuwe Testament verwys ook meermale na 'n gebedshouding (bv. Hand. 9:39, 20:36), Inaar gee geen voorskrif nie. In die Anglikaanse liturgie en in die huweliksfonnulier word die knielende louding behou. Die liggaamshouding behoort met die aard van die gebed te korreleer: kniel wanneer berou op die voorgrond tree, sit wanneer gewag word op die Here en staan wanneer vreugde en oorwinning voorgedra word (vgl. Barnard, 1981: 560 e.v.; Calvyn, 1559: Insititusie 4.10.29-31). In die GKSA word 'n algemene staande houding voorgeskryf omdat die psalm as sang en nie as gebed, boete of belydenisdoen beskou word nie.

\subsection{Die wegstuur}

Die gemeente word met die slotseën van die ontmoeting met God en met mekaar weggestuur om elkeen 'n eie roeping in die volle lewe te volbring. Aan die slotseën is daarom dikwels eksplesiet 'n wegstuurfonmule verbind ('gaan dan heen in vrede') (vgl. GKSA, 1985:420).

\subsection{Christelike handreiking as liturgie}

In Sondag 38 van die Heidelbergse Kategisınus van 1563 word "Christelike handreiking" as 'n prominente motief genoem om saam met die gemeente te vergader om God uit dankbaarherd te dien. Die motief (ook genoem harmhartigherdsdiens) dreig on in die liturgie 'n cliché sonder belewing te word

In die heel vroegste kerke het gelowiges goedere vir die liefdesınaltye gebring (Hand. 4:32, 1 Kor. 11:33; Banard, 1981:574). Soms is ook vir spesiale nood liefdesgawes gegee (Rom. 15:25-28, I Kor. 16:1-3). Calvyn beskou die kollekte as ' $n$ simboliese handeling wat aandui dat ons ons lewe en ons besittings as 'n offer van dankbaarheid aan God gee (Brienen, 1987:219). Kollektebussies is tot onlangs vir dankoffers op die Nagmaaltafel geplaas. Ongelukkig het die gee (insamel) en omgee vir ınekaar (die afdra van gawes) geskei geraak. Die diakens het as tussengangers die gemeente verplaas sodat die diens as geld afdra aan diakens (kollekte) beleef word, terwyl diakens later na goeddunke besluit waar dit uitgedeel word.

Die diens het so veel van sy betekenis as gemeenteliturgie verloor dat die doel van die insameling meesal nie eers afgekondig word nie. Die gewer weet dus nie eers waarvoor hy gee nie en die saak of nood waarvoor gekollekteer word, ontvang nie eers voorbidding in die samekoms nie. Aan die ander kant is hewig ver- 
skil in kerke of die 'kollekte' in die 'erediens' of by die 'deure' opgeneem moes word. Die handeling van 'kollekte' word liturgies swak hanteer

\section{Slotsom}

Die liturgie wat die GKSA uit Nederland geërf het, het uit die staanspoor emstige gebreke vertoon - gebreke wat in ons tyd geaksentueer word. Die voor die handliggende oplossing sou wees om willekeurige eksperimente met die liturgiese orde te doen wamneer sinodale bepalings oor die liturgie nie bevredig nie. Dié weg behoort egter nie opgegaan word nie ondat liturgiese verantwoording nodig is voordat vorme sinvol verander kan word. De Klerk (1987:3) sê tereg:

In Gereformeerde kring is daar oor die erediens baie diskussie ..., maar die gevaar is dat dit meesal nie prinsipieel begrond word nie en dat dit op subjektiewe voorkeure berus. Dikwels ontbreek ' $n$ duidelike beoordelingsinaatstaf ... soms word liturgiese vorme wat in die geskiedenis ontwikkel het, oorbeklemtoon en soms weer onderbeklemtoon ... . As bewys vir bostaande stelling kan op sinodalebesluite oor die vorne van die erediens gewys word ....

Dic oplossing lê daarom nie m die blote verandering van 'liturgiese orde' en losser 'vorme van die erediens' nie. Daar moet verantwoord word w'aarom en hoe die 'vorm' of handeling hanteer en ervaar word. Die Gereformeerdes het hulle sedert 1927 te veel oor die eredien. (vgl. Spoelstra, 1994) as objektiewe verskynsel verantwoord en te min rekenskap gegee van die liturgie as handelinge waarin God ontmoet word

\section{Bibliografie}

BARNARD, A C 1981 Die erediens Pretoria NGKB

BARNARD, AC 1987 Die lewende gebed in die erediens Praktiese Teologie in SiridAfrika, 3:57-73

BEIRITZ, $K$ 199] The Order of Readings and Sermon Text for the German Lutheran Church Sincha lamrgica, 21 (1) 37-5I

BRIENEN, T 1978 Twee in een Hoe God samenkomt met zijn volk De grondvraag van de liturgie Kampen: Kok

BRIENEN, T 1987 De liturgie bij Johannes Calvijn Kampen De Groot-Goudriaan

BRINK, ER 1991. Worship in the CRC A Matter of Grafting The Bamer, 10:12-14, June

BURKHART, JE 1982 Worship, a Searching Examination of the Liturgical Experience Philadelphia Westminster Press

CALVYN, J 1559 Institusie van die Christelike Godsdiens Venaal deur H W Simpson, 1984-1992 4 dele Potchefstroom CJBF

DE JONG, K 1993 Liturgie voor de ontmoetıng ('entrul H'eckblad. 3193315

DE JONG, K W 1990 De openbare eredienst in Friesland rond 1820 Jaarbock wor l.nurghi-()inderzo'k, 6 ।-24

DE JONG, K W 1991 Naar oude gewoonte Juarboek wour l.1/urgle-()nderzock, 7 1-24 
DE KLERK, B J. 1987 Die Heilige Gees en die verhouding Skriflesing, prediking en gebed in die erediens. Potchefstroom PU vir CHO (Th D Proefskrif)

DE KLERK. J J 1990 'n Liturgiese uitsig op God ( $/ n$ Smuts A J, Vos C J A , Nel M reds. In gesprek oor die erediens Pretoria : NG Kerkboekhandel p 8-21)

DE WAARDT, H 1993 What is Happening in South Africa? Trowel and Sirord. 41(7) 3

DEDDENS, K 1981 Waar alles van Hem spreekt, bezinning op de eredienst Groningen

Vuurbaak

DINGEMANS, G D J 1991 Als hoorder onder de hoorders. Kampen Kok

DRESSEL, 1988 Wat is die erediens wat vernuut moet word? Prakricese Ferologic in SuidAfrika, 6:1-14

DU TOIT, J D. 1977. Totius Versamelde Werke Deel 3 Kaapstad : Tafelberg

GEREFORMEERDE KERKE IN SUID-AFRIKA

$k y k$

GKSA, 1862-1985 Handelinge van verskillende Nasionale Sinodes

HARNINK, L 1992 De spiritualiteit van de Psalmen Tijdschrofl voor Laturgie. 76(4) 274283.

HENDRIKS, A N 1983 Om de bediening van de Geest Kampen V'an den Berg

HEYNS, W 1903 Liturgiek ten dienste van de studenten aan de Theologische School der Christelijk Gereformeerde Kerk te Grand Rapids Holland Holkeboer

JONKER, H 1962 Liturgische orientatie, gesprekken over de eredienst Wageningen Somer \& Keunig

JOOSTE, J P 1957 Kom in sy voorhowe Potchefstroom Pro Rege

KUYPER, A. 1911 Onze eeredienst Kampen Kok

LAMBERTS, J 1992 Don Lamben Beaudin en het begin van de liturgische heweging Jaarboek voor Lilurgic-omderzock, 8 235-272

MULLER, J 1987 Vastheid, variasic en kreatiwiteit in die liturgie Prokticice feologge $m$ Sirid-Afrika, 3 34-42

NOORDMANS, O 1986 Verzamelde werken Deel I'l De kerk en hel leven Kampen Kok

OBERHOLSTER, J A S 1956 Die Gereformeerde Kerke onder die Kruis in Surd-Afrika Hul ontstaan en ontwikkeling Kaapstad HAUM

POSTMA, D 1905 De geschiedenis van de stichting en ontwikkeling der Gereformeerde Kerk in Zuid-Afrika Paarl Paarlsche Drukpers

RUNIA. K 1981 Heeft prediken nog zin? Kok Kampen

RUNIA, K 1983 The Sermon under Attack Exeter Paternoster Press

RUNIA, K 1990. Heeft de preek haar tijd gehad? ('entral Weekblad. 39(1)-39(5) 5

RUNIA, K 1991 Intimiteit tussen God en mens ('emraal Weckhlad, 39(47) 5

SPOELSTRA. B 1963 Die "Doppers" in Suid-Afrika Kaapstad Nasionale Boekhandel

SPOELSTRA, B 1989 Gereformeerde Kerkreg en Kerkregering Hammanskraai Teologiese Skool

SPOELSTRA, B 1994 Liturgiese handelinge stel nie vanself ' $n$ erediens as ontmocting met God (godsdiens) daar nie In dre Skriflig 28(1) 37-56

STEIGER, R 1992/3. Suchet der Stadt Bestes Kirchenmusik und Oflentlichkeit Nirngma und Dogma, 38 172-184, Julie-Sept

STOOP, J A A A 1992 Die Klementynse Liturgie Pretoria Unisa

STRYDOM, W M L 1987 Die aard en taak van die himnologie I'rakllese / cologge' in Suld-Afrika. 3:43-56

TANIS, J 1991 East Friesland and the Reformation (al'm Theologicul femmal, 26(2):313-349

THE BANNER. 1992 Always Reforming The Bammer, 127(37) 7 
TRIMP, C. 1983 De gemeente en haar liturgie een leesboek voor kerkgangers Kampen Van den Berg.

VAN DE POL, W. H 1986. Het boek of 'common prayer' (I/l Hasselaar, J M et. al red. Dr O Noordmans, Verzamelde Werken Deel Vl Kampen Kok. p 201-204.)

VAN DE POL, W H 1931 Liturgie Zeist Ploegsma

VAN DER LEEUW, G. 1946. Liturgiek Nijkerk : Callenbach

VAN DER WALT, J J 1982. Soek die Here in sy tempel Potchefstroom : Pro Rege

VAN RONGEN, G 1990. Zijn schone dienst Studies over de gereformeerde liturgie Goes Oosterbaan \& Le Cointre

WAAIJMAN, K 1992. Liturgische spiritualiteit Tijdschrift voor Lıturgie. 76(4) 222-238. 
